\title{
Magnetic intensity loss and core diagenesis in long-core samples from the East Cortez Basin and the San Nicolas Basin (California Borderland)
}

\author{
Carl Richter ${ }^{1}$, Akira Hayashida ${ }^{2}$, Yohan Guyodo ${ }^{3 *}$, Jean-Pierre Valet $^{3}$, and Kenneth L. Verosub \\ ${ }^{1}$ Ocean Drilling Program, 1000 Discovery Drive, Texas A\&M University, College Station, TX 77845-9547, U.S.A. \\ ${ }^{2}$ Science and Engineering Research Institute, Doshisha University, Kyoto 610-0321, Japan \\ ${ }^{3}$ Institut de Physique du Globe de Paris, 4, Place Jussieu, 75252 Paris Cedex 05, France \\ ${ }^{4}$ Geology Department, University of California, Davis, CA 95616, U.S.A.
}

(Received July 16, 1998; Revised May 6, 1999; Accepted May 6, 1999)

\begin{abstract}
We performed high resolution magnetic measurements on about $180 \mathrm{~m}$ of continuous U-channel samples from Sites 1012 (East Cortez Basin) and 1013 (San Nicolas Basin) that were recovered during Ocean Drilling Program Leg 167 to the California Margin. Measurements were made at 1-2 cm intervals from near-complete composite stratigraphic sequences at both of the studied sites with the goal of obtaining high spatial resolution of sediment magnetic properties, including detailed characterization of variations in magnetic mineralogy, concentration, and grain size. The decay of a metastable magnetic mineral or the dissolution of fine-grained magnetite by organic matter reduction had strongly affected both cores, reducing the magnetic intensity to 7\%-10\% of the initial magnetization. Measurements were carried out ca. 4-6 months after the cores were drilled. Despite the reduced magnetic signal we were able to define a stable characteristic remanence for most of the core. Cyclic variations that were observed over short and long stratigraphic intervals are strongly driven at Earth orbital periodicities and have been used to obtain a detailed age model based on comparison with the insolation record.
\end{abstract}

\section{Introduction}

With the development of automated long-core magnetometers that allows rapid and non-destructive measurements of magnetic properties at resolutions of about 1-5 cm, parameters like susceptibility, anhysteretic remanent magnetization (ARM), natural remanent magnetization (NRM), and sedimentary relative paleointensity proxies have become increasingly valuable in paleoceanographic, paleoclimatic, and stratigraphic studies. High-resolution magnetic measurements of sediment samples from the California Margin transect (Ocean Drilling Program Leg 167; Lyle et al., 1997) have yielded records of relative paleointensity, environmental change, diagenetic proxies, and high-resolution magnetostratigraphies (Guyodo et al., in press; Hayashida et al., in press; Hayashida and Verosub, in press; Heider et al., in press; Leonhard et al., in press).

In this study, we report high-resolution rock magnetic results from Sites 1012 and 1013, situated in close proximity in a very similar sedimentary setting in the middle band of California Borderland basins (Emery, 1960). The basins are of tectonic origin and have accumulated thick and continuous sedimentary records that are controlled by discharge from several major rivers and the regional ocean circulation patterns. Sensitive to seasonal and global climatic varia-

*Now at Department of Geology, University of Florida, Gainesville, FL 32611, U.S.A.

Copy right (C) The Society of Geomagnetism and Earth, Planetary and Space Sciences (SGEPSS); The Seismological Society of Japan; The Volcanological Society of Japan; The Geodetic Society of Japan; The Japanese Society for Planetary Sciences. tions is the southerly flowing California Current and the deep Davidson Countercurrent (Soutar and Crill, 1977; Sancetta et al., 1992; Ortiz et al., 1997). Site 1012 is located in $1783 \mathrm{~m}$ water depth in the East Cortez Basin about $100 \mathrm{~km}$ west of San Diego, California (Fig. 1) and Site 1013 is located $68 \mathrm{~km}$ to the northwest in the San Nicolas Basin in slightly shallower water (1564 m, Fig. 1). At locations removed from coarse clastic input the sedimentary column at both sites is rather similar and consists of organic-rich hemipelagic sediment. The deposits are dominated by cyclic alternations between calcareous plankton and terrigenous silt and clay components (Lyle et al., 1997). Both sites yielded an excellent shipboard magnetostratigraphy with relatively strong magnetic intensities $(15 \mathrm{~mA} / \mathrm{m}$ at Site 1012 and $22 \mathrm{~mA} / \mathrm{m}$ at Site 1013 on average) despite relatively high organic carbon contents averaging $1 \%-4 \%$ at Site 1012 and 2\%-9\% at Site 1013, and active methanogenesis in the sediment column (Lyle et al., 1997).

Both sites were cored with the advanced hydraulic piston corer (APC) to about 100 meters below seafloor (mbsf) and deepened with the extended core barrel (XCB) to $270 \mathrm{mbsf}$ (Site 1012) and 146 mbsf (Site 1013). The complete stratigraphic coverage at both sites was ensured by drilling three holes at each site and by matching high-resolution physical property records with a core-to-core correlation technique (Hagelberg et al., 1992; Lyle et al., 1997). Sedimentation rates are high, averaging $65 \mathrm{~m} / \mathrm{m}$.y. at both sites. The APC section reaches the uppermost Pliocene with excellent age control points provided by shipboard magnetostratigraphy and biostratigraphy (Lyle et al., 1997). An isotope stratigra- 


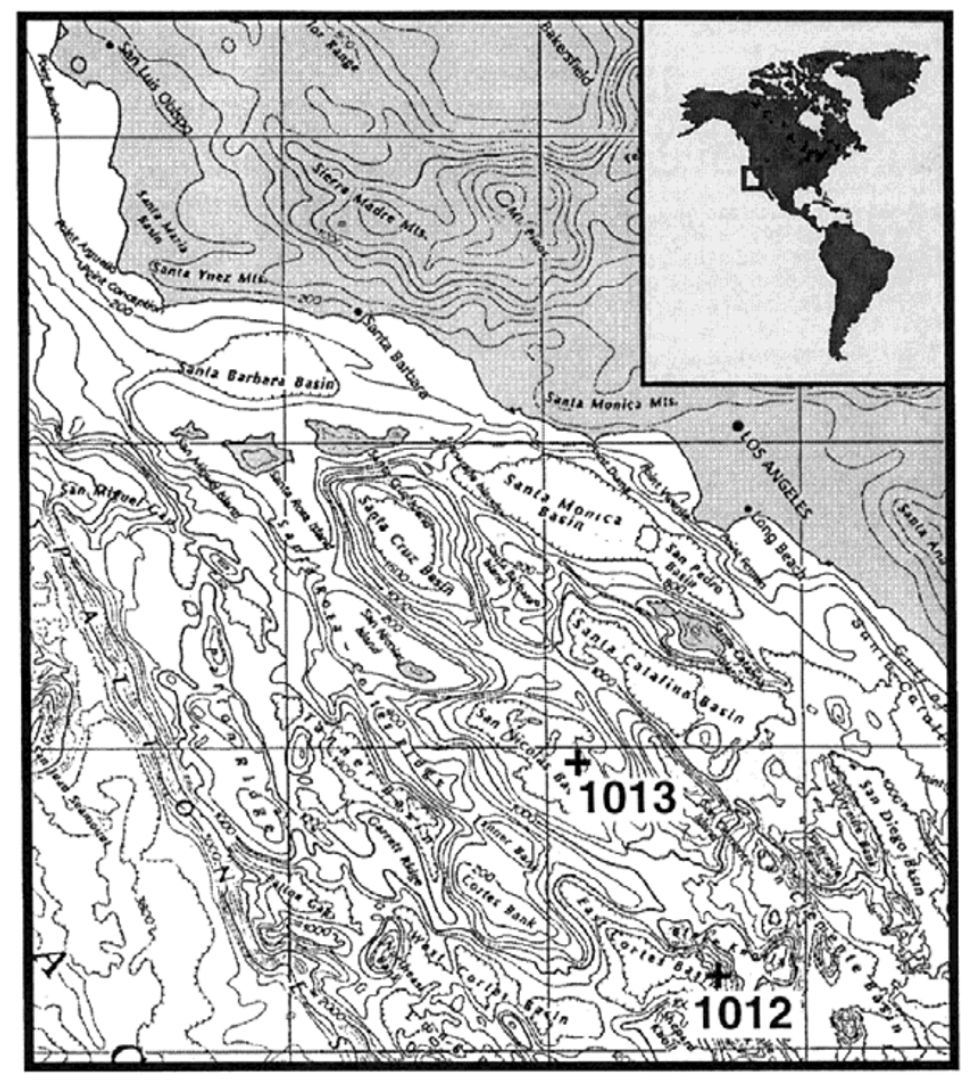

Fig. 1. Location map for Sites 1012 and 1013 in the East Cortez Basin and San Nicolas Basin. Site 1012 is located about $100 \mathrm{~km}$ southwest of San Diego and Site 1013 less than $100 \mathrm{~km}$ southwest of Los Angeles, California.

phy (Andreasen et al., in press) was not available at the time this manuscript was prepared. The sediment at both sites has been affected by diagenetic processes, referred to as core diagenesis, after the initial measurements were taken (about 24 hours after core recovery).

\section{Methods}

Data acquired on shore have been obtained from U-channel samples (Tauxe et al., 1983) collected in the archive halves through the composite sections of Sites 1012 and 1013 (see Lyle et al., 1997). Samples were measured on a narrowaccess $2 \mathrm{G}$ Enterprises cryogenic magnetometer(Weeks et al., 1993; Nagy and Valet, 1993) at the University of California, Davis (Site 1012) and the Institut de Physique du Globe, Paris (Site 1013). U-channel samples were collected by pushing rigid U-shaped plastic liners $(2 \times 2 \mathrm{~cm}$ cross-section, up to $1.5 \mathrm{~m}$ in length) into the archive halves of core sections. Each sample was taken out of the core by guiding a fishing line under the U-channel. A plastic cap was then placed on the U-channel and the ends were sealed to minimize dehydration of the sediment. Magnetic measurements on U-channel samples were made at $1 \mathrm{~cm}$ (Site 1012) and $2 \mathrm{~cm}$ (Site 1013) intervals. However, the half-width of the response function of the magnetometer pick-up coils $(4.5 \mathrm{~cm}$; Weeks et al., 1993 ) is such that adjacent measurements are not independent and the data are slightly smoothed. This might appear as a disadvantage, if compared to a continuous set of discrete samples that can be measured individually (and thus yielding independent results). However, the U-channel method significantly decreases sediment deformation during sampling, and considerably improves the speed at which the measurements can be made.

Prior to U-channel measurements, archive halves of core sections were measured aboard the JOIDES Resolution using a $2 \mathrm{G}$ Enterprises pass-through cryogenic magnetometer at $10 \mathrm{~cm}$ intervals, after alternating field (a.f.) demagnetization at up to $20 \mathrm{mT}$. This wide-access magnetometer has a $15 \mathrm{~cm}$ smoothing window. The natural remanent magnetization (NRM) was measured for all U-channel samples after a.f. demagnetization at 20,30,40,50, and $60 \mathrm{mT}$. An anhysteretic remanent magnetization (ARM) was imparted to the cores from Site 1013 using a $100 \mathrm{mT}$ peak field and a 0.05 $\mathrm{mT}$ bias field and subsequently demagnetized at 20, 30, 40, and $60 \mathrm{mT}$ a.f. field.

U-channel and shipboard magnetic data were compared with volumetric magnetic susceptibility (k) measurements that were made aboard the JOIDES Resolution. Magnetic susceptibility was measured at $3-5 \mathrm{~cm}$ intervals on wholecore sections, after the cores had equilibrated to room temperature for approximately $24 \mathrm{hrs}$, using a Bartington Instruments MS-2 susceptibility meter with an $8 \mathrm{~cm}$ diameter sensing loop that induces a field of $0.1 \mathrm{mT}$ at a frequency of $470 \mathrm{~Hz}$. SI volume units are used throughout. These data were resampled at the resolution of the U-channel measurements to enable direct comparison of results. 
A

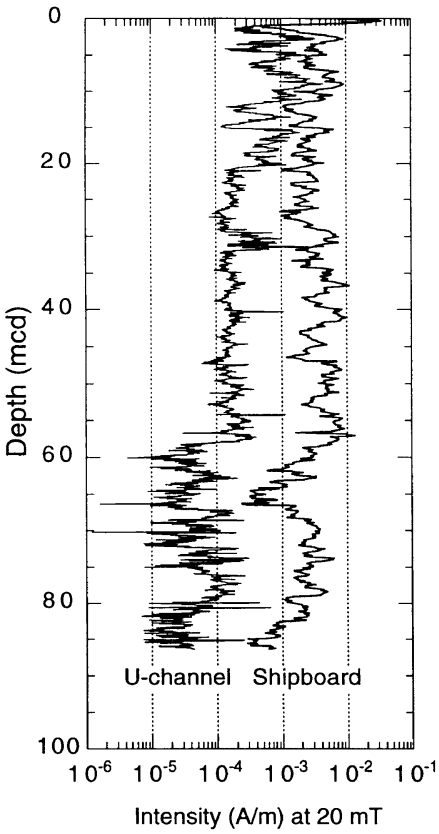

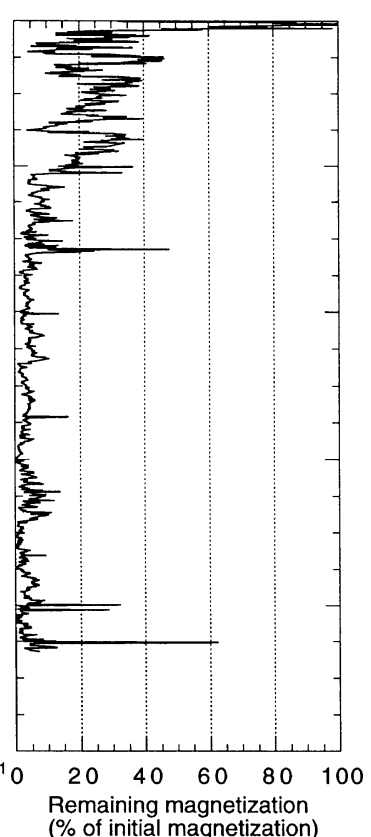

B

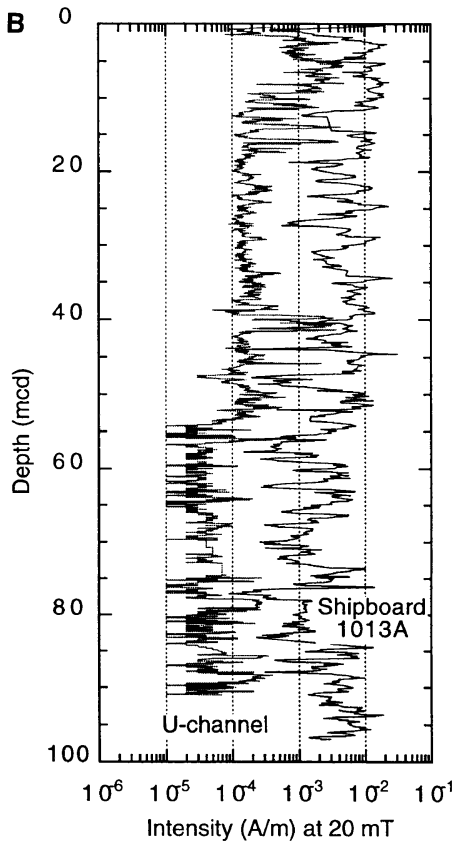

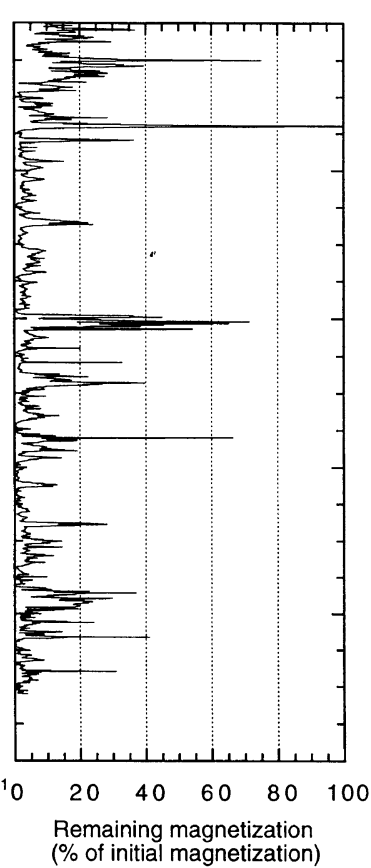

Fig. 2. Shipboard and U-channel magnetic measurements from A. Site 1012 and B. Site 1013 for the interval from 0 to about 90 mcd. Measurements have been resampled at the same depth intervals. Left side panels show magnetic intensity from shipboard measurements of split cores after a.f. demagnetization at $20 \mathrm{mT}$ and of U-channels after a.f. demagnetization at $20 \mathrm{mT}$. Right side panels show loss in NRM intensity between shipboard and U-channel measurements at $20 \mathrm{mT}$ expressed as percent of intensity remaining in the U-channels.
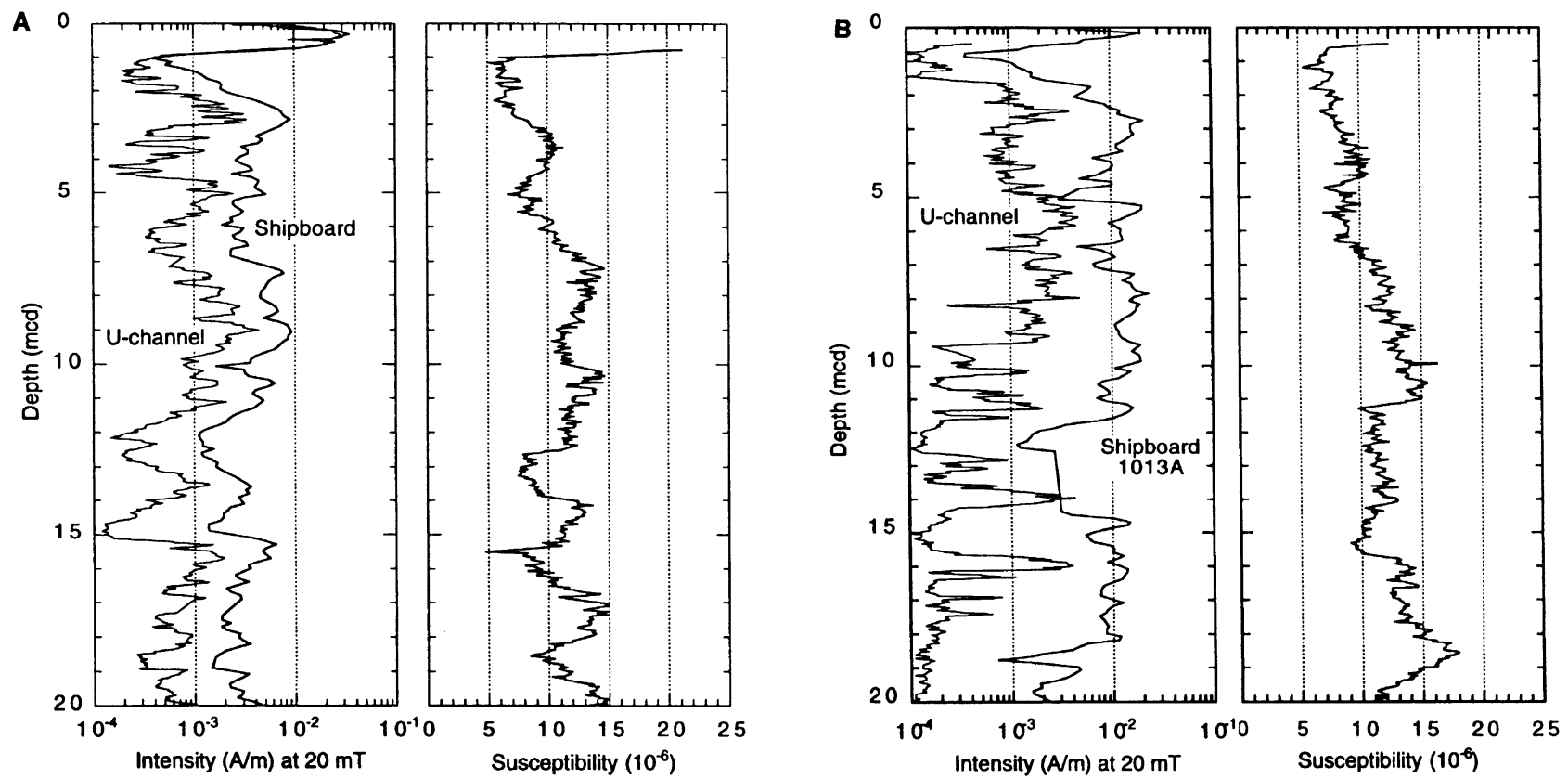

Fig. 3. Comparison between U-channel and shipboard magnetic intensity data and shipboard susceptibility measurements for the uppermost $20 \mathrm{~m}$ at $\mathrm{A}$. Site 1012 and B. Site 1013 .

\section{Results and Discussion}

\subsection{Natural remanent magnetization}

At both sites, the NRM measured after demagnetization at $20 \mathrm{mT}$ (Fig. 2A) contains evidence of cyclic variations which are driven by environmental changes. This feature reflects predominantly variations in magnetic carrier concentration, and to some degree changes in the intensity of the Earth's magnetic field. Intensity of magnetization of the U-channels
(Fig. 2) displays a severe loss when compared to the initial shipboard measurements.

At Site 1012, the remaining intensity of the U-channels was about $10 \%$ on average after the $4-6$ months of storage preceding the U-channel measurements. The loss was particularly significant below 20 meters composite depth (mcd; Hagelberg et al., 1992; Fig. 2A). About $30 \%$ of the initial magnetization had remained between 1 to $20 \mathrm{mcd}$, and the 

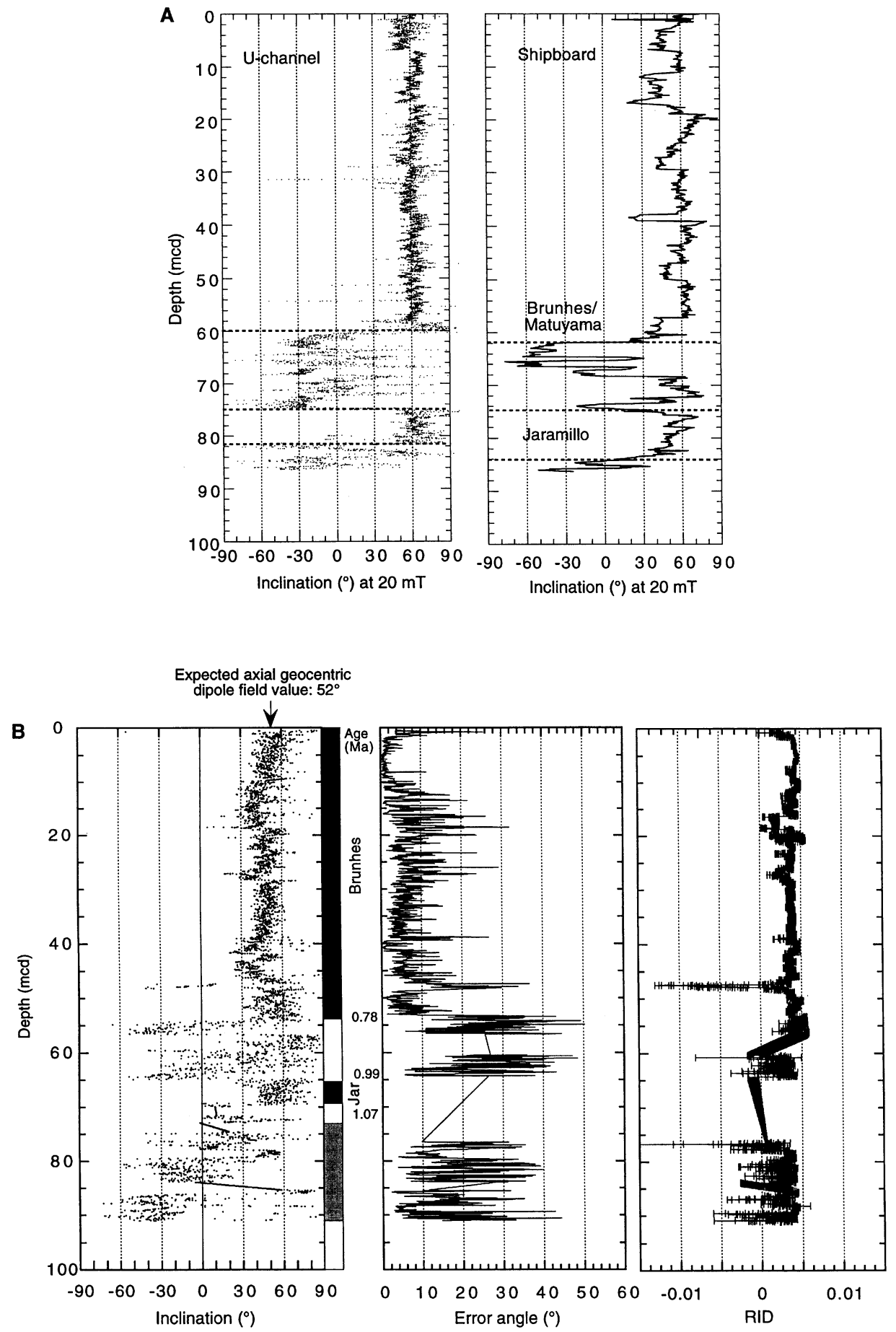

Fig. 4. A. Comparison between U-channel data of magnetic inclination with magnetic polarity interpretation and shipboard data at Site 1012. B. U-channel results of magnetic inclination with magnetic polarity interpretation, error angle, and rate of intensity decrease (RID) with standard deviation at Site 1013 (ages from Cande and Kent, 1995). Despite the severe magnetic intensity loss the magnetic behavior within the Brunhes Chron is acceptable with error angles under or around $10^{\circ}$ and relatively small error bars of the RID which indicate linear behavior during demagnetization.

topmost part suffered no significant loss (Fig. 3A). Both of the shipboard and U-channel data show a downcore intensity drop between 0.8 and $1.0 \mathrm{mcd}$, corresponding to a decrease in magnetic susceptibility measured on board (Fig. 3A). This feature suggests a decrease in magnetic mineral concentration, which can be attributed to dissolution of fine-grained magnetite during reductive diagenesis.

At Site 1013 , only $7 \%$ of the initial magnetization was left on average (Fig. 2B). There are only a few intervals in which $>20 \%$ of the initial magnetic intensity is preserved. The remanence loss is more pronounced in some intervals than in others, therefore altering most of the characteristic features of the shipboard intensity record. Figure 3B shows a direct comparison between the shipboard and the U-channel record for the uppermost $20 \mathrm{mcd}$ in which only a few characteristics of the initial intensity curve are preserved. 


\subsection{Magnetostratigraphy}

Downcore plots of magnetic inclinations from the Uchannels of Site 1012 (Fig. 4A) show that the interval between 0 and $58 \mathrm{mcd}$ has normal polarity, and between 60 and 80 mcd mostly reversed polarity. The weak magnetic intensity in the order of $10^{-5} \mathrm{~A} / \mathrm{m}$ causes considerable scatter of the inclination in the intervals with reversed polarity. Examining both inclination and declination data of stepwise a.f. demagnetization, we interpret that the Brunhes/Matuyama boundary occurs between 58.1 and $60.0 \mathrm{mcd}$. The termination of the Jaramillo Subchron is located between 74.6 and $74.8 \mathrm{mcd}$, and its onset is between 79.9 and $81.9 \mathrm{mcd}$. Comparison of the U-channel and shipboard data (Fig. 4A) suggests that the magnetization measured onboard was more affected by a magnetic overprint in downward direction caused by the drilling process and possibly by a viscous overprint during the Brunhes Chron. We suggest therefore that the magnetostratigraphic datums are better defined by the Uchannel measurements.

Despite this severe remanence loss, the samples behaved well during a.f. demagnetization in the uppermost $50 \mathrm{mcd}$ (Brunhes Chron, Fig. 4B) of Site 1013. A magnetostratigaphy was constructed after determining the mean directions (declination and inclination) of the demagnetization vector. The identification of the primary component of magnetization is usually done graphically in vector component diagrams and intensity decay plots for each sample (Fig. 5). This approach is not possible with the large number of individual measurement points that a U-channel study yields. In order to assess the quality of the demagnetization behavior through the entire sedimentary sequence, we calculated the rate of intensity decrease (RID; Nagy and Valet, 1993) and its standard deviation. The RID is the mean slope of the intensity loss between successive demagnetization steps, after they have been normalized by the initial intensity. Therefore, the RID provides a quantitative evaluation of the demagnetization behavior, and can be plotted as a function of depth. The standard deviation of the RID is used to determine linear or non-linear behavior, where small standard deviations indicate linear demagnetization behavior (Fig. 4B). The char-

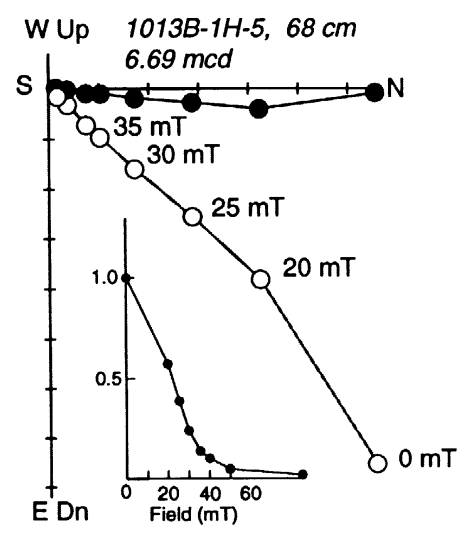

Fig. 5. Vector component diagram for a representative discrete sample from $6.69 \mathrm{mcd}$ at Site 1013. Open (closed) symbols indicate projection onto the vertical (horizontal) plane. acteristic remanent component (ChRM) of the magnetization vector has been automatically calculated (see Nagy and Valet, 1993) by averaging the directions obtained at the 5 demagnetization steps. The error angle (Kirschvink, 1980) at each position is used to determine the dispersion of directions around the mean values. Error angles of $<10^{\circ}$ indicate a well identified single direction while larger values suggest a complex behavior during demagnetization (Fig. 4B). With the exception of anomalous intervals around $15-20$ mcd and at $47-48 \mathrm{mcd}$, both error angle and RID indicate linear demagnetization behavior in the Brunhes Chron (c.f., Fig. 5). The average inclination is $47^{\circ}$, which is close to the expected axial geocentric dipole field value of $52^{\circ}$. We place the Brunhes/Matuyama boundary at $54.5 \mathrm{mcd}$. The deeper part of the section is characterized by large error angles in the order of $20^{\circ}$ to $30^{\circ}$ and unstable demagnetization, as indicated by the RID and the associated large error bars. Despite the fact that the magnetic intensity in the Matuyama Chron is at the detection limit of the magnetometer, a zone of normal polarity between 65 and $69 \mathrm{mcd}$ can clearly be identified as the Jaramillo Subchron (C1r.1n).

\subsection{Age model and rock magnetic parameters}

At Site 1012, the Brunhes/Matuyama boundary occurs at $58.1-60.0 \mathrm{mcd}$ associated with a susceptibility peak. In our age model, this peak is assigned to marine oxygen isotope Stage 19, which is consistent with the age of the Brunhes/Matuyama boundary at $0.78 \mathrm{Ma}$ (Bassinot et al., 1994). We refined the age model within the Brunhes Chron at both sites by tuning the shipboard susceptibility record to the orbital insolation curve (Fig. 6) as depicted by the oxygen isotope record of Bassinot et al. (1994). The correlation between the records is excellent, although we cannot rule out the possibility of other interpretations. Our correlation at both sites is characterized by low susceptibility values during glacials, and high susceptibility values during interglacials. The asymmetry of the warming and cooling cycles with rapid warming and slow cooling phases gives us confidence in this interpretation. The age versus depth diagrams of Fig. 7 show remarkably constant sedimentation rates of very similar magnitude $(74 \mathrm{mcd} / \mathrm{m} . \mathrm{y}$. at Site 1012 and $71 \mathrm{mcd} / \mathrm{m} . \mathrm{y}$. at Site 1013) consistent with the shipboard estimates of Lyle et al. (1997).

To facilitate visual correlation between the different panels displayed in Fig. 6B, we have marked the main lows in magnetic susceptibility (here interpreted as glacial periods) with a gray bar. The anhysteretic remanent magnetization (ARM) is expressed as susceptibility of ARM, $k_{\mathrm{ARM}}(\mathrm{ARM} / 100 \mu \mathrm{T})$ and responds predominantly to the fine-grained magnetite fraction. The pronounced intensity loss, which suggests dissolution of fine-grained magnetite, has a major effect on the $k_{\text {ARM }}$ record. Under ideal conditions (no variation in magnetic mineralogy or magnetic grain size), both $k_{\mathrm{ARM}}$ and low field susceptibility reflect changes in the concentration of magnetic material. In our record, no apparent correlation between the $k_{\mathrm{ARM}}$ and the climatic signal has been found, suggesting partial dissolution of magnetic grains unrelated to cyclic deposition controlled by climate variation. As the dissolution process takes place at the surface of the grain, partial dissolution of magnetic particles generates a relative depletion in smaller sizes. The intervals of high $k_{\mathrm{ARM}}$ values 

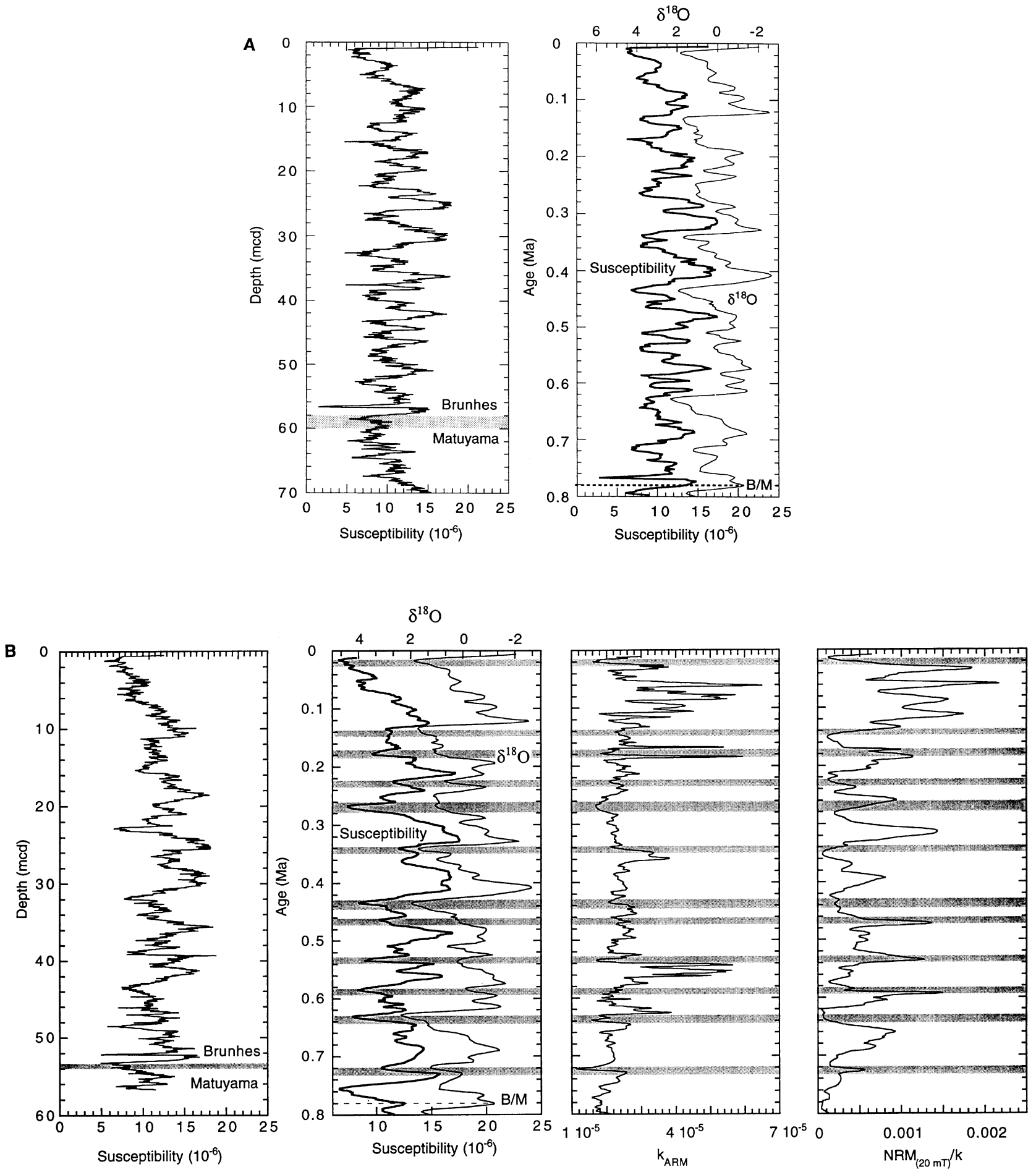

Fig. 6. Shipboard volume magnetic susceptibility of whole-cores (20 pt smooth) versus depth and versus age compared to the oxygen isotope record of Bassinot et al. (1994) A. at Site 1012, and B. at Site 1013. The age model was obtained by tuning the susceptibility to the $\delta^{18} \mathrm{O}$ record. B. Shaded areas denote intervals of low susceptibility which are correlated to times of cool climate and low sealevel. Anhysteretic remanent magnetization (ARM) expressed as $k_{\text {ARM }}$ from U-channel measurements at Site 1013. Shipboard magnetic intensity (Site 1013) after a.f. demagnetization with 20 $\mathrm{mT}$ normalized with magnetic susceptibility. No correlation with the normalizer is apparent, but the lack of quality control prohibits a quantitative interpretation as a relative paleointensity record.

at $0.05-0.12 \mathrm{Ma}(5-10 \mathrm{mcd})$ and $0.54-0.56 \mathrm{Ma}(39-41 \mathrm{mcd})$ would thus correspond to the preserved (or less affected) areas. These two intervals also correspond to the lowest values of the error angle (Fig. 4B), indicating very stable components of magnetization (c.f., Fig. 5) and further supporting our interpretation of the high degree of signal preservation in these two intervals.

We normalized the shipboard magnetic intensity after a.f. demagnetization at $20 \mathrm{mT}$ with the shipboard magnetic susceptibility to test the potential use of the shipboard data as 

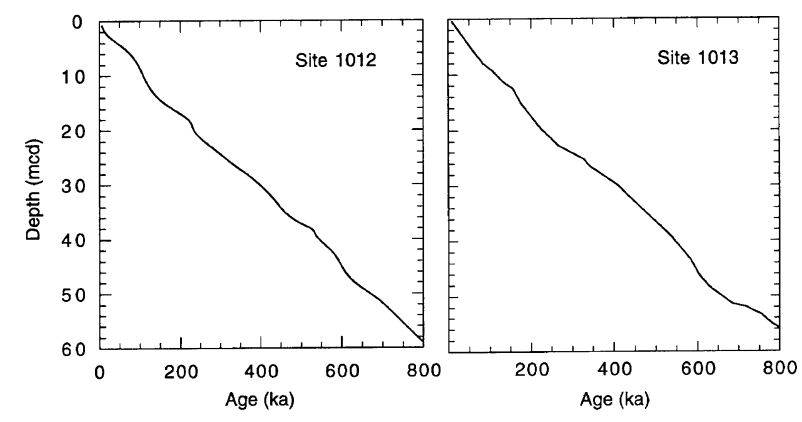

Fig. 7. Age versus depth (mcd) plot shows nearly constant sedimentation rates that are very similar at both sites.

a paleointensity proxy (review in Tauxe, 1993; Valet and Meynadier, 1993) at Site 1013 (Fig. 6B). Within the uncertainties inherent in our age-model, many of the lows in the $\mathrm{NRM} / k$ ratio can be correlated with previously described geomagnetic events (Nowaczyk et al., 1994; Langereis et al., 1997), but the lack of quality control prohibits a quantitative interpretation of this normalized intensity record.

\subsection{Early diagenesis and core diagenesis}

The severe loss of magnetic intensity during the time between the recovery of the cores and the measurements of the U-channels is caused by a loss of magnetic material, either by (1) the dissolution of fine-grained magnetite or (2) the decay of metastable magnetic minerals (e.g., greigite). Both sites are characterized by high organic carbon concentrations (4-8 wt \%), high sedimentation rates around $70 \mathrm{~m} / \mathrm{m} . \mathrm{y}$., and ethane concentrations of around $900,000 \mathrm{ppm}$, indicative of organic matter degradation (Lyle et al., 1997). Sedimentary environments such as this are known for early diagenetic reactions, organic carbon diagenesis by sulfate reduction, and possible authigenic mineralization reactions (Leslie et al., 1990a,b; Roberts and Turner, 1993).

The drop in magnetic intensity and susceptibility observed in the first meter of the shipboard data of both sites (Fig. 3) suggests that the surficial sediments had suffered reductive diagenesis of fine-grained magnetite. The gradual increase of magnetic intensity and susceptibility below $1 \mathrm{mcd}$ may suggest formation of an authigenic magnetic mineral, such as greigite. After the core recovery and shipboard work, these authigenic minerals could decay rapidly under the changed environmental conditions, especially elevated temperature and the presence of oxygen.

Magnetite $\left(\mathrm{Fe}_{3} \mathrm{O}_{4}\right)$ is an iron oxide of mixed oxidation state $\left(\mathrm{Fe}^{2+}, \mathrm{Fe}^{3+}\right)$ that plays a significant role in the diagenesis of marine sediments. Dissolution of magnetic minerals in marine environments can be caused by (1) changing redox conditions, (2) sulfate reduction, (3) biological reduction, and (4) organic carbon oxidation. Biogenic magnetite formation in rapidly-deposited sediments with high organic carbon contents has been observed just above the iron reduction zone (Karlin et al., 1987; Petermann and Bleil, 1993; Tarduno, 1994). Deeper in the sediments, within the iron reduction zone, much of the fine-grained biogenic magnetite and the coarser detrital magnetite is dissolved. The decomposition of organic matter produces light-molecular-weight hydro- carbons and a large amount of $\mathrm{CO}_{2}$ (Hunt, 1979). The $\mathrm{CO}_{2}$ release can cause $\mathrm{CaCO}_{3}$ precipitation if sufficient $\mathrm{Ca}^{2+}$ is present in the pore water and result in the reduction of $\mathrm{Mn}^{4+}$, $\mathrm{Fe}^{3+}, \mathrm{SO}_{4}^{2-}$ by electron transfer from organic carbon, causing the gradual dissolution of magnetite as $\mathrm{Fe}^{3+}$ is reduced to soluble $\mathrm{Fe}^{2+}$ (e.g., Lu and Banerjee, 1994). In sulfate-reducing environments, dissolution of detrital magnetic minerals is wide-spread (Canfield and Berner, 1987), as has been extensively documented in marine sediments. Biological reduction of magnetite by the bacterium Shewanella putrefaciens has been described recently (Kostra and Nealson, 1995) as a very rapid dissolution process at room temperature. Kostra and Nealson (1995) estimate that the rates of remobilization of magnetite through bacterial reduction is in the same order of magnitude as those assumed for the reduction by sulfide.

\section{Conclusions}

Our rock magnetic study of $180 \mathrm{~m}$ of continuous Uchannel samples from two California Borderland basins, the East Cortez Basin and the San Nicolas Basin, suggests that reductive diagenesis had affected the fine-grained magnetite fraction. After the coring process the magnetic intensity was reduced to $7 \%-10 \%$ of the initial magnetization. Possible mechanisms for this intensity loss are the decay of a metastable magnetic mineral, such as greigite, or the dissolution of fine-grained magnetite by organic matter reduction or bacterial activity. We used the stable characteristic remanence to establish a magnetostratigraphic record down to the Jaramillo normal polarity interval. Apparently the Uchannel data were less affected by the coring overprint than the initial shipboard data. Despite the strong diagenetic and core-diagenetic alterations the California Borderland sediments are an excellent recorder of the Earth's magnetic field directions. The magnetic susceptibility recorded a paleoclimate signal that we used in connection with the established oxygen isotope record to obtain a detailed age model within the Brunhes Chron.

Acknowledgments. We are grateful to all members of the ODP Leg 167 shipboard scientific party for numerous discussions. We acknowledge the support and ability of the ODP personnel, Captain E. Oonk, and the crew of the JOIDES Resolution. Careful reviews by Itaru Koizumi, Ted Moore, and EPS reviewers Mike Fuller and Makoto Okada greatly improved the manuscript. This work has been supported by JOI/USSSP grant 167-F000476.

\section{References}

Andreasen, D., M. Flower, M. Harvey, S. Chang, and A. C. Ravelo, Datareport: Late Pleistocene oxygen and carbon isotopic records from ODP Leg 167 Sites 1011, 1012, and 1018. Proceedings of the Ocean Drilling Program, Scientific Results, 167: College Station, TX (Ocean Drilling Program), in press.

Bassinot, F. C., L. D. Labeyrie, E. Vincent, X. Quidelleur, N. J. Shackleton, and Y. Lancelot, The astronomical theory of climate and the age of the Brunhes-Matuyama magnetic reversal, Earth Planet. Sci. Lett., 126, 91108, 1994.

Bloemendal, J., J. W. King, F. R. Hall, and S. J. Doh, Rock magnetism of late Neogene and Pleistocene deep-sea sediments-relationship to sediment source, diagenetic processes, and sediment lithology, J. Geophys. Res., 97, 4361-4375, 1992.

Cande, S. C. and D. V. Kent, Revised Calibration of the geomagnetic polarity timescale for the Late Cretaceous and Cenozoic, J. Geophys. Res., 100, 6093-6095, 1995.

Canfield, D. E. and R. A. Berner, Dissolution and pyritization of magnetite in anoxic marine environments, Geochim. Cosmochim. Acta, 51, 645-659, 
1987.

Emery, K. O., The Sea off Southern California, 336 pp., John Wiley, New Yourk, 1960

Guyodo, Y., C. Richter, and J.-P. Valet, Paleointensity record from Pleistocene sediments (1.4-0 Ma) off the California Margin, J. Geophys. Res., in press.

Hagelberg, T., N. J. Shackleton, N. Pisias, and Shipboard Scientific Party, Development of composite depth sections for Sites 844 through 854, in Init. Repts., 138 (Pt. 1), edited by L. Mayer, N. Pisias, T. Janecek, et al., pp. 79-85, 107: College Station, TX (Ocean Drilling Program), 1992.

Hayashida, A., K. Verosub, F. Heider, and R. Leonhardt, Magnetostratigraphy and relative paleointensity of pelagic sediments at ODP Site 1010 off Baja California, Geophys. J. Int., in press.

Hayashida, A. and K. Verosub, Magnetic characteristics of surficial marine sediments observed in U-channel samples from ODP Leg 167 Sites 1016 and 1017 (California Margin), Geophys. J. Int., in press.

Heider, F., F. Hufenbecher, U. Draeger, and A. Hayashida, The BrunhesMatuyama and the upper Jaramillo transitions recorded in sediments from the California Margin (ODP Leg 167). Proceedings of the Ocean Drilling Program, Scientific Results, 167: College Station, TX (Ocean Drilling Program), in press.

Hunt, J. M., Petroleum Geochemistry and Geology, 615 pp., W. H. Freeman, New York, 1979.

Karlin, R., M. Lyle, and G. R. Heath, Authigenic magnetite formation in suboxic marine sediments, Nature, 326, 490-493, 1987.

King, J. W. and J. E. T. Channell, Sedimentary magnetism, environmental magnetism, and magnetostratigraphy. U.S. Natl Rep. Int. Union Geod. Geophys. 1987-1990, Rev. Geophys., 29, 358-370, 1991.

Kirschvink, J. L., The least-squares line and plane and the analysis of paleomagnetic data, Geophys. J. R. Astr. Soc., 62, 699-718, 1980.

Kostra, J. E. and K. H. Nealson, Dissolution and reduction of magnetite by bacteria, Environ. Sci. Technol., 29, 2535-2540, 1995.

Langereis, C. G., M. J. Dekkers, G. J. deLange, M. Paterne, and P. J. M. Van Santvoort, Magnetostratigraphy and astronomical calibration of the last 1.1 Myr from an eastern Mediterranean piston core and dating of short events in the Brunhes, Geophys. J. Int., 129, 75-94, 1997.

Leonhard, R., F. Heider, and A. Hayashida, Relative geomagnetic field intensity across the Jaramillo Subchron in sediments from the California Margin (ODP Leg 167), J. Geophys. Res., in press.

Leslie, B. W., S. P. Lund, and D. E. Hammond, Rock magnetic evidence for the dissolution and authigenic growth of magnetic minerals within anoxic marine sediments of the California Continental Borderland, J. Geophys. Res., 95, 4437-4452, 1990a.

Leslie, B. W., D. E. Hammond, W. M. Berelson, and S. P. Lund, Diagenesis in anoxic sediments from the California Continental Borderland and its influence on iron, sulfur, and magnetite behavior, J. Geophys. Res., 95,
4453-4470, 1990 b.

Lu, R. and S. K. Banerjee, Magnetite dissolution in deep sediments and its hydrologic implication - a detailed study of sediments from Site-808, Leg 131, J. Geophys. Res., 99, 9051-9059, 1994.

Lyle, M., I. Koizumi, C. Richter, et al., Proceedings of the Ocean Drilling Program, Initial Reports (Part 1), 495 pp., 167: College Station, TX (Ocean Drilling Program), 1997.

Nagy, E. A. and J.-P. Valet, New advances for paleomagnetic studies of sediment cores using U-channels, Geophys. Res. Lett., 20, 671-674, 1993.

Nowaczyk, N. R., T. W. Frederichs, A. Eisenhauer, and G. Gard, Magnetostratigraphic data from late Quaternary sediments from the Yermak Plateau, Arctic Ocean: Evidence for four geomagnetic polarity events within the last $170 \mathrm{ka}$ of the Brunhes Chron, Geophys. J. Int., 117, 453471, 1994.

Ortiz, J., A. Mix, S. Hostetler, and M. Kashgarian, The California current of the last glacial maximum: Reconstruction at 42 degrees $\mathrm{N}$ based on multiple proxies, Paleoceanography, 12, 191-205, 1997.

Petermann, H. and U. Bleil, Detection of live magnetotactic bacteria in South Atlantic deep-sea sediments, Earth Planet. Sci. Lett., 117, 223-228, 1993.

Roberts, A. P. and G. M. Turner, Diagenetic formation of ferrimagnetic iron sulfide minerals in rapidly deposited marine-sediments, South-Island, New-Zealand, Earth Planet. Sci. Lett., 115, 257-273, 1993.

Sancetta, C., M. Lyle, L. Heusser, R. Zahn, and J. P. Bradbury, Late-glacial to Holocene changes in winds, upwelling, and seasonal production of the Northern California current system, Quat. Res., 38, 359-370, 1992.

Soutar, A. and P. A. Crill, Sedimenation and climatic patterns in the Santa Barbara basin during the 19th and 20th centuries, Geol. Soc. Am. Bull., 88, 134-136, 1977.

Tarduno, J., Temporal trends of magnetic dissolution in the pelagic realm gauging paleoproductivity?, Earth Planet. Sci. Lett., 123, 39-48, 1994.

Tauxe, L., J. L. LaBrecque, R. Dodson, and M. Fuller, U-channels-a new technique for paleomagnetic analysis of hydraulic piston cores, EOS Trans. $A G U, \mathbf{6 4}, 219,1983$.

Tauxe, L., Sedimentary records of relative paleointensity of the geomagnetic field: theory and practice, Rev. Geophys., 31, 319-354, 1993.

Valet, J.-P. and L. Meynadier, Geomagnetic field intensity and reversals during the past four million years, Nature, 366, 234-238, 1993.

Weeks, R., C. Laj, L. Endignoux, M. Fuller, A. P. Roberts, R. Manganne, E. Blanchard, and W. Goree, 1993. Improvements in long-core measurement techniques: Applications in palaeomagnetism and palaeoceanography, Geophys. J. Int., 114, 651-662, 1993.

C. Richter (e-mail: Richter@tamu.edu), A. Hayashida, Y. Guyodo, J.-P. Valet, and K. L. Verosub 